\title{
Histórias vividas na llha das Flores (1936- 1955): uma entrevista com a ex-funcionária e ex-moradora Zuleika da Silva Brasil
}

\author{
Juliana Elianay Olimpio de Abreu Pires* \\ Tatiane da Silva Salgueiro** \\ Thiago Rodrigues Nascimento***
}

\section{Introdução}

Nosso propósito é apresentar algumas questões e representações construídas sobre a Hospedaria de Imigrantes da Ilha das Flores, localizada nas proximidades do município de São Gonçalo, região metropolitana do estado do Rio de Janeiro, através de entrevista realizada com uma ex-moradora e funcionária do estabelecimento durante a década de 1950. O depoimento de Zuleika Brasil revela não somente aspectos institucionais, mas a importância que esta localidade representou em sua trajetória de vida, assim como de toda a família. Neste sentido, a partir do seu testemunho, visualizam-se as formas como a Ilha se estruturava objetivando a recepção dos imigrantes que chegavam aos portos do Rio de Janeiro e para lá se encaminhavam.

Zuleika da Silva Brasil nasceu em 30 de junho de 1936, na Ilha das Flores, onde passou sua infância e grande parte da mocidade. Ao lado do pai viveu momentos inesquecíveis, frequentou a escola primária no local junto com filhos de outros funcionários e manteve contato com imigrantes de diferentes

* Licenciada em História pela Faculdade de Formação de Professores da Universidade do Estado do Rio de Janeiro.

** Licenciada em História pela Faculdade de Formação de Professores da Universidade do Estado do Rio de Janeiro.

*** Mestrando do Programa de Pós-Graduação em História Social da Universidade do Estado do Rio de Janeiro. Bolsista da Fundação de Amparo à Pesquisa do Estado do Rio de Janeiro (Faperj). 
regiões do planeta. Quando completou 15 anos, começou a trabalhar na Ilha, exercendo a função de secretária junto ao pai. Trabalhou na Hospedaria de Imigrantes de 1951 a 1955, quando optou por se transferir para outro órgão do governo federal, deixando a Ilha com a família.

São histórias comuns, mas que permitem "ouvir vozes de pessoas que não fazem parte da história dominante” (Thompson apud Fonseca, 2010, p. 37). Trata-se de uma representação individual acerca de suas próprias experiências de vida e de um modelo de imigração presente na história brasileira até a primeira metade do século passado. As nossas conversas ocorreram em junho de 2009, na casa da depoente.

\section{Considerações sobre a llha das Flores}

A antiga Ilha de Santo Antônio, a partir da primeira metade do século XIX, passou a ser denominada nos documentos oficiais como Ilha das Flores, por ter pertencido, nesse período, a Delfina Felicidade do Nascimento Flores. Originalmente, era uma fazenda destinada à piscicultura e foi adquirida pelo senador do império José Silveira da Mota ${ }^{1}$ que, em 1854, tornou-se proprietário de um pequeno arquipélago na Baía de Guanabara, formado pelas ilhas Mexingueira, Ananazes e das Flores. O arquipélago foi adquirido pelo Império, que criou a Hospedaria de Imigrantes da Ilha das Flores no ano de $1883 .{ }^{2}$ De imediato, a Hospedaria ficou sob a tutela do Ministério da Agricultura.

A Inspetoria Geral de Terras e Colonização, órgão do Ministério da Agricultura, foi criada por meio do decreto-lei de 23 de fevereiro de 1876, ficando incumbida de regulamentar as questões referentes à imigração e ao povoamento das terras brasileiras. $\mathrm{O}$ estabelecimento deste órgão aconteceu numa conjuntura em que discussões estavam sendo realizadas em torno de um projeto

1 Em 1811, nasceu no estado de Goiás José Inácio Silveira da Mota que, entre outros cargos políticos, foi deputado provincial e senador. Era pai de Artur Silveira da Mota, que teve uma participação expressiva na Guerra do Paraguai, tornando-se um personagem histórico para a Marinha do Brasil, o Barão de Jaceguai.

2 O registro oficial de inauguração da Hospedaria da Ilha das Flores é do ano de 1883, entretanto, há documentos que mostram que o primeiro livro de registro de imigrantes desta hospedaria data de 1877 . Neste ano, porém, só constam os meses de junho, julho, agosto, setembro, outubro, novembro e dezembro, não tendo continuação nos anos seguintes $(1878,1879$, 1880, 1881 e 1882). A partir de 1883, os livros de registros, que se encontram no Arquivo Nacional, acusam a entrada de imigrantes encaminhados para a Ilha das Flores até o ano de 1932, quando a chegada dos imigrantes passou a ser registrada apenas nos livros do porto. 
do governo imperial de incentivo à imigração. Tais discussões se baseavam em três políticas imigratórias: a primeira está relacionada à substituição da mão de obra escrava pela imigrante; a segunda, com a necessidade e a preocupação do governo brasileiro em povoar áreas fronteiriças até então desocupadas; a terceira, de certa forma, perpassava as políticas anteriores e era baseada na teoria do branqueamento, que pregava a possibilidade de o Brasil "civilizar-se" a partir do gradual embranquecimento de sua população (Ribeiro, 2008).

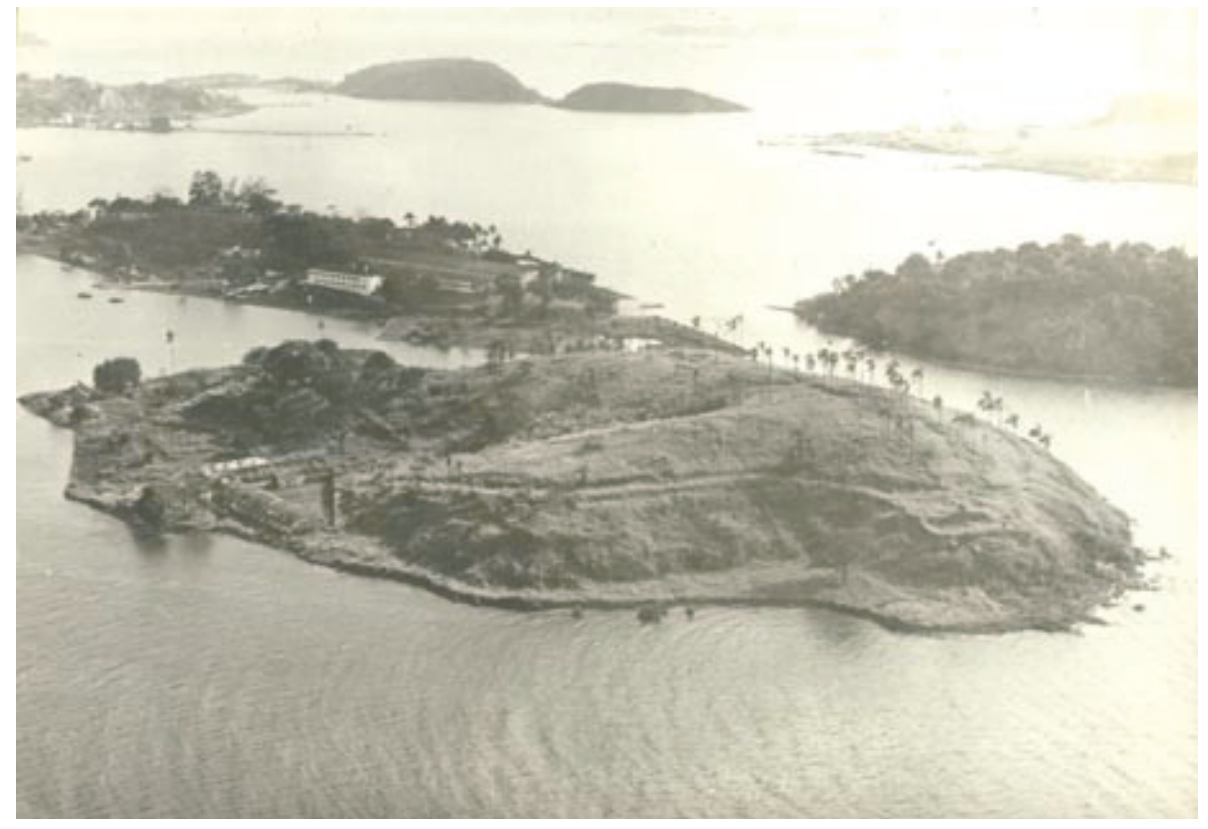

Figura 1. O conjunto de ilhas na Baía de Guanabara, Rio de Janeiro (Fonte: Projeto História de São Gonçalo: Memória e Identidade³).

É neste contexto que foi criada a Hospedaria de Imigrantes da Ilha das Flores. Ela funcionou sob o poder do Ministério da Agricultura até 1917, quando passou provisoriamente para a responsabilidade do Ministério da Marinha (Decreto no 12.689/1917) por uma questão de Segurança Nacional, retornando para o primeiro através do decreto $\mathrm{n}^{\circ} 13.781$ de $1^{\circ}$ de

3 A fotografia pertence ao acervo do Projeto História de São Gonçalo: Memória e Identidade, da Faculdade de Formação de Professores (FFP), da Universidade do Estado do Rio de Janeiro (Uerj). 
outubro de 1919. O Ministério da Agricultura deixou de responder pela Ilha das Flores em 1931, quando o Ministério do Trabalho foi incumbido de tal tarefa, através do Departamento Nacional de Povoamento. A Ilha, enquanto hospedaria de imigrantes, funcionou até 1966, recebendo neste ano um total de 85 imigrantes.

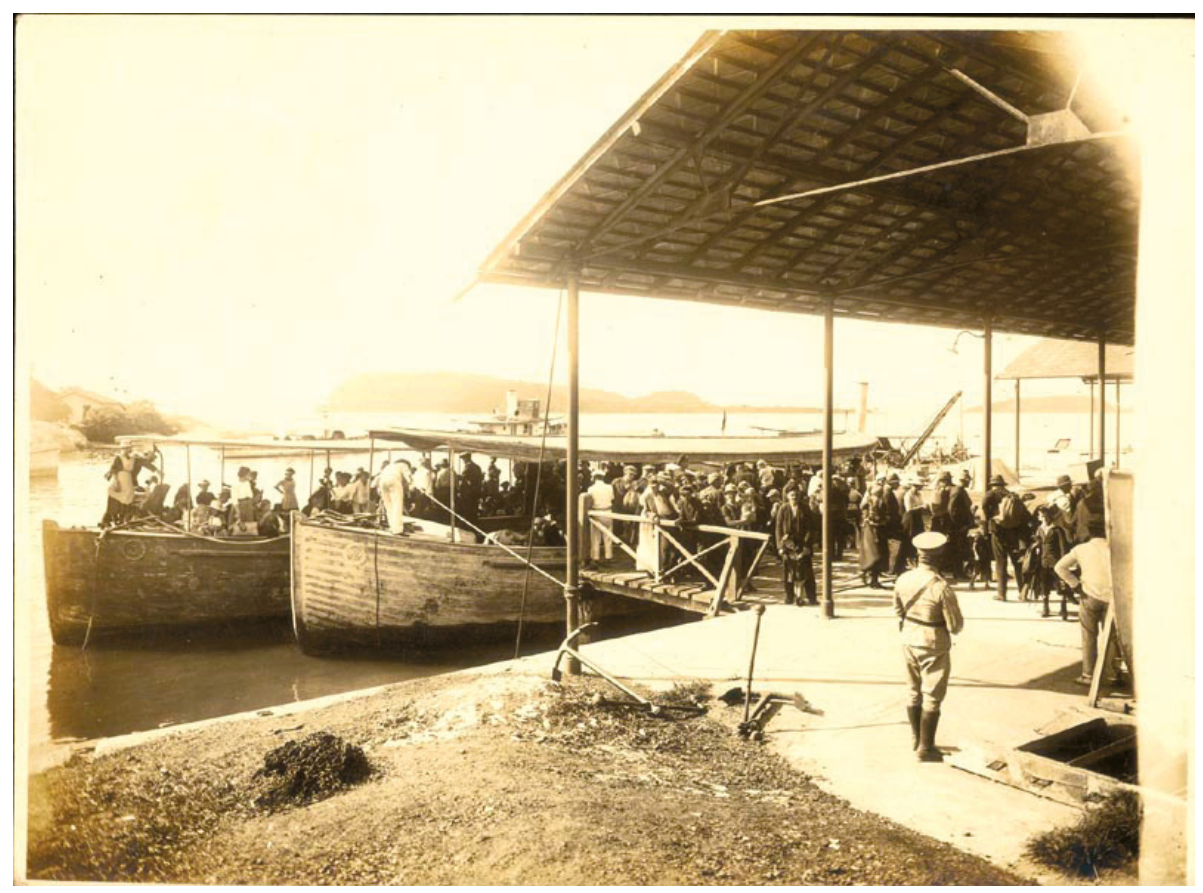

Figura 2. Chegada de imigrantes no cais da Hospedaria de Imigrantes da Ilha das Flores (Fonte: Acervo Leopoldino Brasil, UERJ ${ }^{4}$ ).

Em seu quase um século de existência a Ilha teve outros usos. A Hospedaria, em 1915, abrigou temporariamente pessoas sem teto. ${ }^{5}$ No ano de 1932, funcionou como presídio, detendo os combatentes da Revolução

4 A fotografia faz parte do acervo Leopoldino Brasil, que integra o projeto História de São Gonçalo: Memória e Identidade, da Faculdade de Formação de Professores (FFP), da Universidade do Estado do Rio de Janeiro (Uerj).

5 Segundo reportagem de 04 de maio de 1915, publicada no jornal O Fluminense, que se encontra na Biblioteca Nacional, no Rio de Janeiro. 
Constitucionalista e, três anos mais tarde, a ilha recebeu os revoltosos da Intentona Comunista. Durante a Segunda Guerra Mundial, em 1945, aprisionou alemães ligados ao Eixo e foi utilizada como presídio político a partir de 1969, após a decretação do AI-5, de 13 de dezembro de 1968 - durante os anos do regime militar. Dez anos depois, em 1978, a Ilha foi transferida oficialmente para a Marinha do Brasil. ${ }^{6}$

Para além da centralidade espacial da Hospedaria, localizada a 10 quilômetros da Praça XV, regiáo central da cidade do Rio de Janeiro, ela tinha uma função essencial. Era o primeiro ponto do território brasileiro em que o imigrante, depois de ter atravessado um oceano, colocava os pés e construía suas primeiras impressões do país; era também onde ocorria a distribuição desses estrangeiros pelo interior do Brasil.

\section{Breves apontamentos sobre a História Oral}

Paul Thompson argumenta que, até as primeiras décadas do século XX, o enfoque da História era fundamentalmente político, sendo dada pouca atenção às vidas das pessoas comuns. Nesse contexto, o historiador privilegiava o documento político e escrito (Thompson, 1992, p. 22).

Ao longo das últimas décadas, sobretudo a partir dos anos 1980, a História Oral tem se tornado fonte e ferramenta importante para os historiadores que se dedicam a analisar processos históricos recentes ou buscam, nas palavras de Lucília Delgado (2006, p. 15), "recuperar informações sobre acontecimentos e processos que não se encontram registrados em outros tipos de documentos [...]". Desta forma, a História Oral descortina uma série de processos que antes ficavam ocultos, permitindo aos historiadores o acesso a diferentes testemunhos e tornando possível novas interpretações do passado. A História Oral, de acordo com Thompson, é uma História construída em torno de pessoas e permite que grupos, antes desconsiderados, como o dos idosos, tenham a oportunidade de ser ouvidos (Thompson, 1992, p. 44).

Neste sentido, consideraremos a definição de História Oral formulada por Lucília Delgado (2006, p. 15): “[...] é um procedimento metodológico que busca, pela construção de fontes e documentos, registrar, através de

6 A transferência oficial data de 1978, mas desde 1968 a Marinha do Brasil tem a posse da Ilha das Flores, onde hoje funciona uma base de Fuzileiros Navais. 
narrativas induzidas e estimuladas, testemunhos, versões e interpretações sobre a História em suas múltiplas dimensões”. Desta forma, objetiva-se, no presente artigo, utilizando-se a História Oral, apresentar o depoimento da senhora Zuleika e a sua versão ou interpretação do passado, mais especificamente, suas representaçóes acerca de sua experiência de vida na Ilha das Flores, percebendo nas suas palavras as contribuições que o contato com os imigrantes proporcionou a ela.

\section{A entrevista}

\section{A família e a infância na llha das Flores}

Pergunta - A senhora poderia falar um pouco sobre a história do seu avô? Como é que seu avô foi para a Ilha das Flores?

Zuleika da Silva Brasil - Eu sei que ele era da Ilha. Sempre escutamos dizer que ele e minha avó eram da Ilha. Meu avô era pernambucano, dizia ele, inclusive, que era da terra de Lula, de Garanhus. Ele dizia que era de lá. E minha avó era cearense. Casaram, e minhas tias nasceram lá [na Ilha] e meu pai não. Meu avô era funcionário da Agricultura, iam pra lá justamente para, vamos dizer assim, colonizar a repartição, começar a repartição, em decorrência da dificuldade da distância. A Sede (do órgão da Imigração) era no Rio, no centro do Rio de Janeiro. Então, ficava difícil contratar, então, eles pegavam pessoas que eram mais daqui, da região de São Gonçalo. Acho que talvez tenha sido por isso que meu avô foi para lá, e lá ele se estabeleceu e veio a família toda.

P - Um pouco sobre a sua família. O seu pai nasceu na Ilha?

ZSB - Não, meu pai nasceu na Gávea, pois minha avó, quando veio do Ceará, se mudou para esta região... Tinha uns parentes que moravam na Gávea, então, ela foi morar lá, onde ele [o pai] nasceu. Depois foi que vieram morar aqui em Neves e depois foram pra Ilha. Devia ser bem jovem ainda, tanto que minhas tias - as irmãs dele - nasceram lá na Ilha; a diferença de idade não é tão grande assim. Vivas ainda tem duas, uma já morreu e um irmão também morreu. Então, agora da família do meu pai só tem duas tias, uma que mora em São Paulo e a outra aqui. Elas estão bem idosas, mas ainda lembram muitas coisas. 
$\mathbf{P}-\mathrm{E}$ os seus pais?

ZSB - Meu pai chamava-se Leopoldino Brasil e minha mãe Maria de Fátima da Silva Brasil. Minha mãe era portuguesa, veio com a família toda pra cá, mas não passou pela Ilha das Flores como imigrante. Depois do casamento é que eles foram morar lá. Meus avós já moravam lá, depois eles saíram, vieram morar aqui fora.

P - A senhora disse que seu avô trabalhava na Ilha, e seu pai?

ZSB - Ele contava que naquela época tinha ido fazer um concurso para inscrição para trabalho em algum lugar, mas então um conhecido dele perguntou: "você quer trabalhar na Ilha?". Ele disse: "quero", então "vamos pra lá"; e foi para lá e na mesma hora ficou, porque naquela época a procura era bem menor do que a oferta. A mão de obra não existia pra trabalhar, por exemplo, na Ilha, porque era um regime de quartel, que tinha todo aquele horário, a gente dependia daquela lancha para entrar e sair da Ilha, então era difícil, por isso os funcionários moravam na própria Ilha.

P - Quais foram as funções que o seu pai exerceu na Ilha?

ZSB - Oficialmente o cargo que ele ocupava era o cargo de "faz tudo", existia uma vaga e ele entrou naquela vaga, mas lá era praticamente um administrador, era o braço direito, vamos dizer assim, o que conhecia tudo, porque o cargo de diretor era um cargo político, virava e mexia mudava, então eles chegavam lá e não conheciam e era meu pai que conhecia toda a estrutura.

P - A instalação de seu pai na Ilha, como se processou?

ZSB - Alguns funcionários moravam lá porque... por causa da necessidade do trabalho e porque a Ilha das Flores ficava distante da cidade do Rio de Janeiro. A condução nos levava até a Praça XV, nós tínhamos a lancha que ia até a Praça XV, que era a Sede do Ministério do Trabalho e gastava-se de lancha uma hora e pouco para lá e uma hora e pouco pra cá. Então, quem era funcionário não aceitava vir todo dia, então, eles criaram um núcleo lá, [em] que os trabalhadores mais necessários morassem com suas famílias. Não era muita gente não, umas poucas famílias, e eu tive essa felicidade, esse privilégio de ser uma das escolhidas pra viver lá, eu e minha família. 
P - Quantos irmãos a senhora teve?

ZSB - Hierarquicamente tem a Cleide, tem eu, aí vem a Ivone e mais três irmãos menores. Éramos cinco mulheres e três homens. Um irmão agora mora lá em Santa Rosa, outro mora em Macaé e outra mora lá em Santa Catarina e o restante ficou por aqui, a gente vive por aqui em São Gonçalo mesmo. Já casaram, já tem netozinhos.

P - Vocês nasceram na Ilha?

ZSB - Nós nascemos na Ilha, todos com parteira, nenhum de nós nasceu em hospital. Os oito filhos que a mamãe teve foram com parteira e, graças a Deus, todos perfeitos, todos se criaram, só perdemos um irmão já adulto, já estava até casado. E cada um de nós tem uma história. A Cleide, por exemplo, nasceu no carnaval.

P - Quando a senhora nasceu?

ZSB - Em 36, 30 de junho de 36. Dia mais lindo do ano!

P - Como foi a sua infância na Ilha das Flores?

ZSB - Nós tínhamos um time de futebol: Centro Esportivo Ilha das Flores, que fazia de tudo. Vinha time de fora jogar. Nosso time ia jogar fora e a turma ia. A gente tinha nossa torcida organizada e tínhamos uma vida bem intensa, bem ativa. Todo domingo nós tínhamos nosso bailezinho. A gente vivia muito mais intensamente na Ilha do que fora. Lá tinha tudo. Tudo o que se pode imaginar tinha de lazer. Da janela lá de casa, a gente via os botos passando quando a maré 'tava cheia, numa distância curta, o mar passava ali, perto de casa, os botos nadavam, a arraia dava aqueles pulos. A gente pegava muita variedade de peixes, tinha tudo isso lá. Na época nos tínhamos tudo isso!

$\mathbf{P}-$ E o contato com os imigrantes?

ZSB - A gente convivia muito com os imigrantes, a gente conversava, a gente brincava com as crianças e aprendíamos as brincadeiras deles, as canções, assim como eles aprendiam as nossas, então, era aquele intercâmbio, a gente 
ensinava, eles ensinavam e compartilhávamos culturas diferentes. Ambos saíamos ganhando.

P - E o Ensino? A Ilha das Flores tinha uma escola?

ZSB - Tinha. Tinha uma professora que ia de fora, que era designada "funcionária”. E era uma escolinha que tinha uma única turma, de primeira a quarta série, tudo junto. Quando terminávamos o primário, é que tínhamos que vir estudar cá fora, porque lá não tinha...

P - Como era esta escola na Ilha? Cursou todo o ensino regular na Ilha?

ZSB - A escola era aquele grupinho pequeno. Só aquela... menino, menina, tudo junto. Então, quando a gente saiu e foi estudar cá fora, tinha o deslumbramento, porque você vai sair de uma escola de cinco, seis pessoas que você nasceu e criou junto... e entrar num colégio de turma mista, com meninos com a cabeça mais avançada que a gente.

\section{A visão da imigração, a vida e o trabalho na llha das Flores}

P - A imigração! O que a senhora sabe sobre a imigração e a fundação da Ilha das Flores?

ZSB - A imigração começou com a abolição da escravatura. Quando foi abolida a escravidão, foi que se falou em imigração, porque a gente ficou sem mão de obra. Então, inclusive tem novelas que contam essa história. Existia a imigração e a hospedaria em Santos e depois criaram a da Ilha das Flores. A Ilha das Flores era uma fazenda particular de um cidadão que se chamava seu Flores, então, ficou Ilha das Flores. O Ministério da Agricultura comprou a Ilha. Primeiro, antes de ser hospedaria de imigrantes, ela funcionou ali como estação experimental. Ali eles fizeram tratamento, ${ }^{7}$ isso aí já não foi do meu tempo, mas papai sempre contava histórias de como eles plantaram essas frutas que tinha na Ilha, que a gente não conhece, por exemplo, oiti, frutas que

7 Segundo Dona Zuleika, antes de a Ilha se tornar um lugar de recepção de imigrantes, era uma estação experimental de plantação de frutas oriundas de outras regiốes. 
são mais tropicais, que são de outras regiões, eram plantadas todas nessa região lá da Ilha das Flores. Hoje não sei mais se tem abricó, oiti, sapoti. Frutas que foram plantadas nesse período. Tinha também viveiros e criação de peixes. Peixes de várias espécies, que eram criados lá e depois eram vendidos para os mercados, para as peixarias e coisa e tal. Mas isso já é outra história. Depois então a imigração pegou, porque só tinha em Santos e existia um número grande de imigrantes que vinham trazidos pra cá.

$\mathbf{P}$ - Depois que a Ilha se tornou um polo receptor de imigrantes, como funcionava a estrutura da imigração?

ZSB - Esse serviço era feito da seguinte forma: o Departamento de Imigração tinha uma equipe que ia à Europa, de preferência em um país que foi mais prejudicado pela guerra, então, as pessoas estavam lá sem nada. Nós aqui sabíamos que tinha um grupo de pessoas que estava querendo vir pra cá, formava-se uma equipe, que ia buscá-los. Os fazendeiros aproveitavam esta mão de obra para trabalhar nas fazendas de café, que era a nossa produção principal. E, então, eles pediam: "quero tanta mão de obra", e trazíamos. A preferência era por japoneses que eram especializados em agricultura. Os imigrantes já vinham prontos para esse núcleo, [para] essas regiões. Os imigrantes, a maioria dava preferência para a Região Sul, por causa do clima. Clima mais parecido com o deles, que a gente, quando ia pra lá, mostrava o que tinha aqui no Brasil e eles vinham. Eles vinham pra cá [a Ilha das Flores], para fazer a triagem e a documentação. Começava pelo serviço de saúde que a imigração tinha.

$\mathbf{P}$ - A senhora tem noção de quantas pessoas trabalharam na Ilha nesse período, da infância da senhora?

ZSB - Bom, era mais ou menos assim, como se fosse uma cidadezinha pequena. Então, começava com o cais de embarque. Tinha marinheiros que moravam lá, uma família. Aí tinha a lavanderia, que geralmente recebia as roupas de cama e o refeitório. Cada um tinha os seus responsáveis. Aí tinha o resto da administração, parte de limpeza, parte de outro tipo de cuidado. Uma média de 20 a 30 funcionários que moravam na Ilha. Faziam revezamento. Era dia e noite. 
P - Como era a chegada dos imigrantes à Ilha?

ZSB - Primeira coisa, o navio ficava ao largo, não encostava, aí tinha o serviço de saúde pública. Ministério da Saúde, Ministério do Trabalho e os ministérios responsáveis iam lá fazer a vistoria, porque às vezes nessa turma vinha gente com doença $e$, para não trazer doença para nós, fazia-se o serviço. $E$ nessa visita iam médicos, sanitaristas, iam vários funcionários da Ilha. Lá eles faziam a visita, se tivesse tudo bem, liberava imigrantes e passavam para a nossa embarcação. Quando chegavam na Ilha, eles encontravam um cartaz enorme, isso eu nunca esqueci, porque desde pequenininha - quando eu falo dá até vontade de chorar - [havia] um cartaz enorme que dizia assim: "Você era um estranho e o Brasil o acolheu", isso escrito em alemão, polonês, japonês, vários idiomas; eu sei o que diziam, que eu não entendia, mas embaixo estava em português. Isso pra mim era uma coisa linda.

P - Quanto tempo os imigrantes permaneciam na Ilha?

ZSB - Eles vinham, passavam pela Ilha, faziam essa triagem, primeiro da parte de saúde, depois fazia a documentação, geralmente eles ficavam lá no prazo de um mês mais ou menos, às vezes até menos. Aí, quando terminava tudo isso, eles estavam aptos a embarcar, aí a própria repartição, o próprio governo, providenciava o embarque deles, iam até o Galeão, lá eles pegavam aquele avião da Aeronáutica, avião da $\mathrm{FAB}$, e embarcavam.

P - Qual era a estrutura de funcionamento da Ilha?

ZSB - Tinha o refeitório, tinha os alojamentos, que eram divididos, e a enfermaria. Tinha três pavilhões principais, um hospital, tinha o hospital de isolamento. Família, rapaz solteiro, moças que vinham sozinhas, família com criança ficavam nos alojamentos e tinham tudo direitinho. Tinha a lavanderia que eles passavam e já recebiam roupa de cama, tudo, tudo que se pudesse imaginar de conforto para a estadia deles a repartição fornecia. O refeitório para eles almoçarem.

P - Então a Ilha era toda estruturada?

ZSB - Tinha toda uma estrutura. 
P - Quando a senhora começou a trabalhar na Ilha? E quais as atividades que a senhora fazia na Ilha?

ZSB - Eu nem pensava, nem sonhava em trabalhar, em ser funcionária, mas a gente vivenciava aquilo, e os filhos dos funcionários acabavam sendo aproveitados. Eu comecei a trabalhar em 51. Serviço geral de escritório, era datilógrafa, trabalhava na secretaria, tanto que depois fiquei como auxiliar de administração dentro do plano do Ministério, que não tinha mais nada a ver. Mas na Ilha eu trabalhei pouco tempo, porque logo depois a gente optou pelo Ministério do Trabalho, em 1955. No Ministério trabalhei no Departamento de Pessoal, de 1955 a 1981.

P - A senhora morou na Ilha até quando?

ZSB - Até 1955, quando foi extinto o órgão, foi extinta a imigração e passou a pertencer ao... na época era o... INIC, Instituto Nacional de Imigração e Colonização, que hoje é o Incra. Aí foi mudando e dizia que não ia ter vida própria, é... seria uma autarquia, então, a gente podia optar pelo Ministério do Trabalho. Como já estávamos, de alguma forma, vinculados a este Ministério, acabamos optando por ele, aí foi quando a gente saiu de lá, foi em 1955. Depois que deixei o trabalho na Ilha das Flores, trabalhei até 1982 no Ministério do Trabalho, quando me aposentei.

$\mathbf{P}$ - Teve algum caso importante, e de que a senhora se lembre, envolvendo os imigrantes?

ZSB - Tinha muitas situações, inclusive uma das situações que para mim é mais pitoresca e a mais importante: que a minha tia caçula, irmã do meu pai, casou com um imigrante que passou por lá, ela casou, teve uma filha com ele. Ela mora em São Paulo, ela é viva ainda. Ele foi embora para o Paraná com a família, e manteve correspondência com a minha tia, ela tinha uns 12 ou 13 anos, ele tinha 14 ou 15. Anos depois, quando ele chegou à idade adulta, já estabilizado em São Paulo, aí veio aqui, se encontraram e casaram e foram morar em São Paulo e viveram felizes para sempre [risos]. Ele, o meu tio (por casamento), era polonês. Os imigrantes realizavam uma coisa interessante. Houve uma época em que os europeus, totalmente desprovidos de certos preconceitos nossos, mudavam a roupa na praia, assim, com a maior naturalidade, e os funcionários, por conta disso, só queriam varrer e cuidar 
daquele pedaço [risos]. Eles iam com a família tomar banho, com a maior naturalidade, chegava lá, tirava a roupa, entravam na praia com a maior naturalidade, as famílias todas, como hoje tem as colônias de nudismo, que é uma coisa privativa.

$\mathbf{P}$ - Quais os tipos de eventos (festas) que aconteciam na Ilha?

ZSB - Ah, tinha as festas, as festas tradicionais. Depois foi criado um serviço de recreação operária, que pertencia ao Ministério do Trabalho, e todo dia $1^{\circ}$ de maio eles faziam uma festança grande lá. Tipo um piquenique, em que iam aqueles "mocanhê", nem sei se ainda existe. Levava o pessoal, os operários, aí era a confraternização, tinha almoço, tinha churrasco.

$\mathbf{P}$ - Os imigrantes participavam?

ZSB - Participavam de tudo que tinha lá. Nós tínhamos os bailes, que eram realizados aos sábados e domingos. Nos bailes tocavam muita valsa, então, era aquela confraternização dos imigrantes e dos familiares, dos funcionários, a gente participava muito ativamente. Não tinha distinções.

P - Os imigrantes tinham permissão para sair da Ilha?

ZSB - Tinham. Eles tinham permissão para sair quando queriam ir ao Rio ou a Niterói. Meu pai é que dava a permissão. Eles não eram prisioneiros, eles tinham a vida deles normal, vinham cá fora e faziam compras, cambiar dólar e tudo. Eles... aprendiam logo tudo, andavam com máquina fotográfica e comportavam-se na verdade quase como uns turistas de hoje, só que lá na Ilha eles ficavam justamente para se documentar, se orientar e se acostumar aos hábitos do país.

P - Havia imigrantes que vinham sem contrato de trabalho?

ZSB - Vinham todos os tipos de imigrantes, aqueles que queriam vir, chegavam lá, se inscreviam e vinham, chegavam aqui e muitos ficavam por aqui mesmo. Porque vinha muita gente qualificada, vinham muitos engenheiros, vinham muitas pessoas gabaritadas. Existia na Ilha um trabalho de triagem e indicação para aqueles que vinham sem contrato de trabalho ou local definido de trabalho. 


\section{A vida depois da llha das Flores}

P - Quando acabou a hospedaria, quando acabou a parte de imigração, como foi esse processo para a sua família?

ZSB - Fomos morar no Barreto. Até nisso nós tivemos uma vantagem. Porque na época o nosso Instituto era o IPASE. Depois foi que fez essa separação aí. Essa fusão, né? $\mathrm{Na}$ época cada órgão tinha seu Instituto: IPASE, IAPI, IAPTEC, tudo. Então, toda pessoa, vamos dizer assim, que era despejada tinha uma prioridade em relação a empréstimo para compra de casa. E por nós termos optado pelo Ministério, praticamente fomos consideradas como despejadas. Meu pai recebeu um documento pedindo o nosso desligamento do órgão [Ilha das Flores] e entregamos a casa. ${ }^{8}$ E claro que a gente tinha que entregar! Não tinha nada a ver a gente ficar lá. E aquilo valeu como se fosse uma ordem de despejo. E com isso a gente apresentou ao IPASE e conseguimos um financiamento, onde compramos essa casa. ${ }^{9}$

\section{Considerações finais}

As marcas da experiência de ter nascido e vivido parte da juventude na Ilha das Flores ainda estão presentes no discurso da entrevistada, expressando de maneira peculiar suas vivências, suas percepções sobre um determinado fato ou lugar. Ao longo do tempo, vão se aperfeiçoando suas explicações de acordo com as novas experiências adquiridas. Hoje, ela tem a possibilidade de analisar de longe (no tempo) fatos que viveu. Assim, a memória vai sendo construída no decorrer dos anos.

A lucidez e a riqueza de detalhes com que a entrevistada relatou os momentos vivenciados na Ilha das Flores demonstram a importância da localidade tanto na vida dessa família como para a história da cidade de São Gonçalo, região metropolitana do estado do Rio de Janeiro.

A infância da senhora Zuleika Brasil foi marcada por divertimentos, tais como time de futebol, bailes, torcidas organizadas. Segundo ela, "a gente

8 A casa em que a família vivia na Ilha das Flores pertencia ao governo.

9 A casa atual, onde a dona Zuleika vive com as irmãs Cleide e Ivone. 
vivia muito mais intensamente lá do que fora. Lá tinha tudo. Tudo o que se pode imaginar tinha lá de lazer”. A educação primária era oferecida nas instalações da Ilha por uma professora que, de acordo com D. Zuleika, vinha “[...] de fora, que era designada funcionária”, entretanto, somente frequentavam essa escola os filhos dos funcionários que habitavam o local. Ela ainda relata que "eram uma turma toda, de primeira a quarta série, tudo junto"; logo, a relação escolar entre os alunos era uma extensão da relação que mantinham fora da escola, uma espécie de família. Desta forma, quando teve que sair da ilha para continuar os estudos, percebeu a grande diferença entre estudar numa escola de "cinco, seis pessoas, [em] que você nasceu e criou junto [...] e entrar no colégio de turma mista". Para ela, os alunos de fora da Ilha tinham "a cabeça mais avançada" que os de dentro.

A história da Ilha antes de seu nascimento ou mesmo de sua participação é muito relacionada às experiências do seu pai, mas percebemos que há certa apropriação de um determinado viés historiográfico de explicação da imigração no Brasil e da criação da Hospedaria de Imigrantes. Em 1951, então com 15 anos, começou a trabalhar como datilógrafa na secretaria da Ilha, sendo responsável pela parte burocrática de entrada de imigrantes, marcação de nomes nos livros de registro, formação de equipes para auxiliar na acomodação dos imigrantes, entre outras tarefas. O cargo que ocupou serviu para que, depois de sua saída da Ilha, em 1955, pudesse exercer a função de auxiliar administrativa do Ministério do Trabalho.

As lembranças da senhora Zuleika são construídas, em grande parte, em torno do período da sua vida na Ilha das Flores. A impressão que tivemos é que esse período marcou profundamente a sua história de vida: neste lugar ela cresceu enquanto pessoa e intelectualmente, devido ao constante contato com diversas pessoas, imigrantes, provenientes de diferentes lugares. $\mathrm{O}$ seu depoimento contribuiu para nortear nossa pesquisa sobre o tema, uma vez que trouxe informações extremamente preciosas, do ponto de vista da investigação histórica, ao conceder não apenas uma entrevista, mas também documentos provenientes do tempo em que morou e trabalhou na Ilha. Percebemos que a forte a relação que a família da entrevistada estabeleceu com a Ilha; os laços de afetividade não foram rompidos passado mais de meio século desde que deixaram o local. 


\title{
Referências
}

DELGADO, L. de A. N. História Oral, memória, identidades. Belo Horizonte: Autêntica, 2006.

RIBEIRO, F. A. dos S. A politica imigratória a partir da ilha das Flores, em São Gonçalo (1883-1902). São Gonçalo: UERJ, 2008.

THOMPSON, P. História e comunidade. In: THOMPSON, P. A voz do passado. 2. ed. Rio de Janeiro: Paz e Terra, 1992. p. 20-40.

Resumo: A história da imigração no Brasil vem merecendo destaque nas pesquisas historiográficas ao longo das últimas décadas. As primeiras medidas visando à imigração para o país se iniciam ainda no período imperial, quando é fundada a Hospedaria de Imigrantes da Ilha das Flores, em 1883, no Rio de Janeiro. Apesar da importância que ela teve para a história brasileira, muitos fluminenses e brasileiros conhecem pouco sobre este lugar. Nosso objetivo é apresentar algumas questões e representações construídas sobre a Hospedaria de Imigrantes da Ilha das Flores, localizada nas proximidades do município de São Gonçalo, região metropolitana do estado do Rio de Janeiro, através de entrevista realizada com a ex-moradora e funcionária Zuleika Brasil.

Palavras-chave: imigração, Ilha das Flores, histórias de vida.

Histories lived on the Island of Flores (1936-1955): an interview with the former employee and former resident Zuleika da Silva Brasil

\begin{abstract}
The history of immigration in Brazil has a special focus on historical research over the past decades. The first measures aimed at immigration to the country began even in the imperial period, when it founded the Migrant Hostels of Flores Island, in 1883, in Rio de Janeiro. Besides the importance that she had for the history of the country, many of brazilians, born in Rio de Janeiro, knows little about this place. Our goal is to present ideas and representations built on the Immigrant Hostel Flores Island, located near the municipality of São Gonçalo, a metropolitan region of Rio de Janeiro state, through an interview with former resident and employee of the same Zuleika Brasil.
\end{abstract}

Keywords: immigration, Flores Island, life histories.

Recebido em 12/08/2011

Aprovado em 20/10/2011 